\title{
PENERAPAN UNSUR KEALPAAN DALAM PROSES PENYIDIKAN TINDAK PIDANA KECELAKAAN LALU LINTAS
}

\author{
Yuliantoro \\ Kepolisian Resort Tegal \\ yuliantoro4512@gmail.com
}

\begin{abstract}
This study aims to determine the application of the element of negligence in the process of investigating traffic accidents and to find out the obstacles in the application of the negligence element in the traffic accident investigation process. The method used is the normative juridical approach. Normative research or also known as library law research is legal research carried out by examining library material or secondary data only, then to be applied to research problems, namely the application of negligence elements in the process of investigating traffic accidents, so that its presentation stems from the principles and theories and doctrines as well as applicable legislation. Based on the research it can be concluded that 1) the application of the Traffic Accident Crime is when the relationship between the inner perpetrator and the consequences arising from the act or there is an outward relationship which is a causal relationship between the offender's actions and the prohibited consequences, so that the suspect can be applied elements negligence resulting in the death of another person and 2) Obstacles in the application of the Traffic Accident Crime is the opinion of the suspect and the public in general that accidents that occur on the highway are pure accidents and cannot be criminally accounted for so that the community, especially victims, will forgive the suspect in this crime of negligence.
\end{abstract}

Keyword: Investigation, Negligence, Traffic Accident Crime

\section{A. PENDAhuluan}

Indonesia adalah Negara hukum yang berdasarkan Pancasila dan Undang-Undang Dasar Negara Republik Indonesia Tahun 1945 dengan menjunjung tinggi nilai moral, etika, akhlak dan kepribadian luhur bangsa, beriman dan bertakwa kepada Tuhan Yang Maha Esa, serta menghormati kebinekaan dalam kehidupan bermasyarakat, berbangsa dan bernegara serta melindungi harkat dan martabat setiap warga 
negara. Sesuai dengan perkembangan ilmu pengetahuan dan teknologi khususnya teknologi informasi dan komunikasi telah memberikan andil terhadap meningkatkan perbuatan, penyebarluasan dan penggunaan pornografi yang memberikan pengaruh buruk terhadap moral dan kepribadian luhur bangsa Indonesia sehingga mengancam kehidupan dan tatanan sosial masyarakat Indonesia. Pembangunan hukum nasional meliputi etika pembangunan hukum nasional, Kebijakan Pembangunan Hukum Nasional dan Kebijakan pembangunan hukum nasional. ${ }^{1}$

Tugas Pokok Kepolisian Negara Republik Indonesia sesuai Undang-undang Nomor 2 Tahun 2002 tentang Kepolisian Negara Republik Indonesia dimana keamanan dalam negeri dirumuskan sebagai format tujuan Kepolisian Negara Republik Indonesia dan secara konsisten dinyatakan dalam perincian tugas pokok yaitu memelihara keamanan dan ketertiban masyarakat, menegakkan hukum serta melindungi, mengayomi dan melayani masyarakat. Salah satu tugas Kepolisian Negara Republik Indonesia adalah melakukan penyidikan. Penyidikan adalah serangkaian tindakan penyidik dalam hal dan menurut cara yang diatur dalam Undang-undang untuk mencari serta mengumpulkan bukti yang terjadi dan guna menemukan tersangkanya².

Berdasarkan data dari National Traffic Management Center Kepolisan Negara Republik Indonesia tahun 2011 yang lalu telah terjadi 2.770 kecelakaan lalu lintas dengan korban 449 orang tewas, 760 orang luka berat dan 1.914 orang luka ringan. Demikian pula berdasarkan buku "Mudik Asik" yang dikeluarkan Mabes Polri, jumlah kecelaan lalu lintas pada arus mudik menjelang dan sesudah lebaran

${ }^{1}$ Andri Winjaya Laksana, Suratman, Analisis Yuridis Penyidikan Tindak Pidana Pornografi Berdasarkan Undang-Undang Nomor 44 Tahun 2008 Di Era Digitalisasi, Jurnal Pembaharuan Hukum, Volume I No. 2 Mei - Agustus 2014, hlm.169-177.

2 Teguh Prasetyo, 2010. Hukum Pidana, Raja Grafindo Persada, Jakarta, h. 65 
tahun 2012 sebanyak 927 kecelakaan dengan korban tewas sebanyak 182 orang, luka berat 261 orang dan 497 orang luka ringan. ${ }^{3}$

Dalam Berkas Perkara Nomor BP/09/V/2013, Tersangka Suparlan bin Sukarjo telah diperiksa oleh petugas Penyidik Polres Tegal karena telah melakukan kelalaian sehingga telah mengakibatkan orang lain meninggal dunia yang diatur dan diancam dalam Pasal 310 Undang-undang Nomor 22 Tahun 2009 tentang Lalu Lintas dan Angkutan Jalan Raya.

Dari berbagai banyak kejadian kecelakaan tersebut dapat disimpulkan bahwa faktor kelalaian dan kekuranghati-hatian pengemudi yang banyak memicu kecelakaan. Faktor manusia merupakan penyebab utama terjadinya kecelakaan lalu lintas di jalan raya. Hal tersebut terjadi karena adanya kecerobohan atau kealpaan pengemudi dalam mengemudikan kendaraannya.

Kecerobohan pengemudi tersebut tidak jarang menimbukan korban, baik korban menderita luka berat ataupun meninggal dunia bahkan tidak jarang menyebabkan orang yang terdekat seperti keluarga, istri bahkan anaknya sendiri menjadi korban. Beberapa kecelakaan lalu lintas yang terjadi, sebenarnya dapat dihindari bila di antara pengguna jalan bisa berperilaku disiplin, sopan dan saling menghormati di mana penggunaan jalan tersebut diatur di dalam Undang-undang Nomor 22 Tahun 2009 tentang Lalu Lintas dan Angkutan Jalan

Menurut Pasal 310 Undang-undang Nomor 22 Tahun 2009 tentang Lalu Lintas dan Angkutan Jalan bahwa apabila kealpaan atau kelalaian pengemudi itu mengakibatkan orang lain terluka baik luka ringan maupun luka berat atau bahkan meninggal dunia maka ancaman piudananya sebagaimana diatur dalam pasal-pasal tersebut

${ }^{3}$ http:investor.co.id/home/pemerintah-dinilai-tak-serius-jalankan-zero-accident 
di atas.

Pada Berkas Perkara Nomor BP/09/V/2013 di mana tersangka dijerat dengan Pasal 310 Undang-undang Nomor 22 Tahun 2009 tentang Lalu Lintas dan Angkutan Jalan di mana di dalam Pasal 310 ayat (4) Undang-undang Nomor 22 Tahun 2009 tentang Lalu Lintas dan Angkutan Jalan memiliki unsur-unsur yakni unsur setiap orang, unsur yang mengemudikan kendaraan bermotor, unsur karena lalai dan unsur mengakibatkan meninggalnya orang lain.

Dalam Berkas Perkara Nomor BP/09/V/2013, unsur kedua (yang mengemudikan kendaraan bermotor) dan unsur ketiga (mengakibatkan meninggalnya orang lain) telah terpenuhi. Hanya unsur kedua yakni karena lalai, yang harus dibuktikan di persidangan. Melalui proses penyidikan polisi, unsur keempat tersebut akan dibuktikan.

Pasal 234 ayat (3) Undang-undang Nomor 22 Tahun 2009 tentang Lalu Lintas dan Angkutan Jalan menyatakan bahwa ketentuan Pasal 234 pada ayat (1) dan (2) Undang-undang Nomor 22 Tahun 2009 tentang Lalu Lintas dan Angkutan Jalan tidak berlaku jika

1. Adanya keadaan memaksa yang tidak dapat dielakkan atau di luar kemampuan pengemudi

2. Disebabkan oleh perilaku korban sendiri atau pihak ketiga, atau Disebabkan oleh adanya gerakan orang atau hewan meskipun telah dilakukan tindakan pencegahan.

\section{B. METODE PENELITIAN}

Metode yang digunakan adalah metode pendekatan yuridis normatif. Penelitian normatif atau disebut juga penelitian hukum kepustakaan adalah penelitian hukum yang dilakukan dengan cara meneliti bahan pustaka atau data sekunder, kemudian untuk 
diterapkan pada masalah penelitian yakni penerapan unsur kealpaan dalam proses penyidikan tindak pidana kecelakaan lalu lintas Nomor BP/09/V/2013 di Polres Tegal, sehingga penyajiannya berpangkal pada asas-asas dan teori-teori dan doktrin serta perundang-undangan yang berlaku. ${ }^{4}$

\section{HASil PENELITIAN DAN PEMBaHASAN}

\section{Penerapan Unsur Kealpaan dalam Proses Penyidikan} Tindak Pidana Kecelakaan Lalu Lintas Nomor BP/09/V/2013 di Polres Tegal

Penerapan terhadap Tindak Pidana Kecelakaan Lalu Lintas Nomor BP/09/V/2013 di Polres Tegal adalah ketika hubungan antara batin pelaku dengan akibat yang timbul karena perbuatannya itu atau ada hubungan lahir yang merupakan hubungan kausal antara perbuatan pelaku dengan akibat yang dilarang itu, sehingga kepada tersangka dapat diterapkan unsur kealpaan yang mengakibatkan meninggalnya orang lain yang diatur di dalam Pasal 310 Undang-undang Nomor 22 Tahun 2009 tentang Lalu Lintas dan Angkutan Jalan di mana di dalam Pasal 310 ayat (4) Undang-undang Nomor 22 Tahun 2009 tentang Lalu Lintas dan Angkutan Jalan memiliki unsur-unsur sebagai berikut unsur setiap orang, unsur yang mengemudikan kendaraan bermotor, unsur karena lalai dan unsur mengakibatkan meninggalnya orang lain.

Dalam Berkas Perkara Nomor BP/09/V/2013 dengan Tersangka Suparlan bin Sukarjo telah diperiksa oleh petugas Penyidik Polres Tegal karena telah melakukan kelalaian sehingga telah mengakibatkan orang lain meninggal dunia yang diatur dan

${ }^{4}$ Salim HS dan Erlies Septiana Nurbani, 2013, Penerapan Teori Hukum pada Penelitian Tesis dan Disertasi, Raja Grafindo Persada, Jakarta, h. 12. 
diancam dalam Pasal 310 Undang-undang Nomor 22 Tahun 2009 tentang Lalu Lintas dan Angkutan Jalan Raya. Di mana kejadiannya secara singkat adalah bahwa pada hari Rabu tanggal 10 April 2013 sekira jam 09.00 Wib, di jalan raya A Yani Slawi Wilayah Kelurahan Procot Kec. Slawi Kab. Tegal antara Kbm Toyota kijang No.Pol. G-8681-D yang melaju dari arah selatan menuju utara sewaktu mendahului Kbm Truck yang indentitasnya tidak diketahui yang melaju searah ada didepannya Kbm toyota kijang tersebut oleng kekiri kemudian menabrak Sam honda Supra X 125 No.Pol. G-3160-BZ yang melaju dari selatan menuju utara ( searah ada didepannya ) yang kemudian menabrak tembok taman dan pohon palem yang berada di sebelah barat jalan -dan mobil terbalik dengan posisi roda ada di atas, akibat kejadian kecelakaan lalu lintas tersebut penumpang Kbm toyota kijang No.Pol. G-8681D, 5 ( lima ) orang meninggal dunia dan 5 ( lima ) orang mengalami luka Iuka di rawat di RSUD Dr. Soesilo Slawi. sebagaimana di maksud dalam Pasal 310 ayat (2), (3) dan (4) Undang Undang Nomor 22 tahun 2013 tentang Lalu Lintas dan angkutan jalan. sehubungan dengan Laporan Polisi No.Pol.: LP/ 180 / IV / 2013 / Lantas, tanggal 10 Bulan April 2013.

Pada Berkas Perkara Nomor BP/09/V/2013 di mana tersangka dijerat dengan Pasal 310 Undang-undang Nomor 22 Tahun 2009 tentang Lalu Lintas dan Angkutan Jalan di mana di dalam Pasal 310 ayat (4) Undang-undang Nomor 22 Tahun 2009 tentang Lalu Lintas dan Angkutan Jalan memiliki unsur-unsur sebagai berikut unsur setiap orang, unsur yang mengemudikan kendaraan bermotor, unsur karena lalai dan unsur mengakibatkan meninggalnya orang lain.

Dalam Berkas Perkara Nomor BP/09/V/2013, unsur kedua 
(yang mengemudikan kendaraan bermotor) dan unsur ketiga (mengakibatkan meninggalnya orang lain) telah terpenuhi. Hanya unsur kedua yakni karena lalai, yang harus dibuktikan di persidangan. Melalui proses penyidikan polisi, unsur keempat tersebut akan dibuktikan.

Di dalam berkas perkara tersebut penerapan unsur kelalaian dapat dijelaskan karena kendaraan yang kerap kali menghantui kecelakaan adalah fungsi rem, kondisi ban, hingga pencahayaan. ada beberapa faktor yang menyebabkan kendaraan mengalami kecelakaan lalu lintas, seperti terbalik atau menabrak, faktoor tersebut diantaranya adalah Genangan air, pecah ban, jalan bergelombang, rem blong ataupun Slip, human error,

Kesengajaan dan kealpaan pada dasarnya sama, sama dalam arti di dalam lapangan hukum pidana, kealpaan itu mempunyai pengertian yang khusus. Menurut Noyon-Langemeyer: "kealpaan adalah suatu struktur yang sangat susah diartikan. Dia mengandung dalam satu puhak kekeliruhan dalam perbuatan lahir dan menunjuk kepada keadaan batin yang tertentu, dan di lain pihak keadaan batinnya itu sendiri". Selanjutnya dikatakan, jika dimengerti demikian, maka culpa mencakup semua makna kesalahan dalam arti luas yang bukan berupa kesengajaan.

Beda kesengajaan dengan kealpaan ialah bahwa dalam kesengajaan ada sifat yang positif yaitu adanya kehendak dan penyetujuan yang disadari daripada bagian-bagian delik yang meliputi oleh kesengajaan, sedang sifat positif ini tidak ada dalam kealpaan. Oleh karena itu dapat dimengerti, bahwa dipakai istilah yang sama untuk kesalahan dalam arti yang luas dan kesalahan dalam arti yang sempit, meskipun ini tidak praktis.

Sekarang perlu kita selidiki lagi apakah artinya atau isinya 
kealpaan itu di dalam Berkas Perkara Nomor BP/09/V/2013. Sebagaimana halnya dengan kesengajaan mengenai kealpaan ini juga diterangkan dalam KUHP tentang artinya. Karena itu maka kita harus melihat pada teori atau ilmu pengetahuan untuk memberi pengertiannya ini. Van Hamel mengatakan bahwa kealpaan itu mengandung dua syarat yaitu

a. Tidak mengadakan penduga-duga sebagaimana diharuskan oleh hukum.

b. Tidak mengadakan penghati-hatian sebagaimana diharuskan oleh hukum.

Untuk melihat apakah seseorang dapat disangka melakukan tindak pidana kealpaan, maka harus ditentukan apakah pelaku tindak pidana melakukan kesalahan dengan sengaja (do/us) atau kelalaian/ Kealpaan (culpa).

Dalam lapangan hukum pidana, unsur kesengajaan atau yang disebut dengan opzet merupakan salah satu unsur yang terpenting. Dalam kaitannya dengan unsur kesengajaan ini, maka apabila didalam suatu rumusan tindak pidana terdapat perbuatan dengan sengaja atau biasa disebut dengan opzettelijk, maka unsur dengan sengaja ini menguasai atau meliputi semua unsur lain yang ditempatkan dibelakangnya dan harus dibuktikan.

Sengaja berarti juga adanya kehendak yang disadari yang ditujukan untuk melakukan kejahatan tertentu. Maka berkaitan dengan pembuktian bahwa perbuatan yang dilakukannya itu dilakukan dengan sengaja, terkandung pengertian menghendaki dan mengetahui atau biasa disebut dengan willens en wetens. Yang dimaksudkan disini adalah seseorang yang melakukan suatu perbuatan dengan sengaja itu haruslah memenuhi rumusan willens atau haruslah menghendaki apa yang ia perbuat dan 
memenuhi unsur wettens atau haruslah mengetahui akibat dari apa yang ia perbuat.

Di sini dikaitkan dengan teori kehendak yang dirumuskan oleh Von Hippel maka dapat dikatakan bahwa yang dimaksudkan dengan sengaja adalah kehendak membuat suatu perbuatan dan kehendak untuk menimbulkan suatu akibat dari perbuatan itu atau akibat dari perbuatannya itu yang menjadi maksud dari dilakukannya perbuatan itu.

Jika unsur kehendak atau menghendaki dan mengetahui dalam kaitannya dengan unsur kesengajaan tidak dapat dibuktikan dengan jelas secara materiil karena memang maksud dan kehendak seseorang itu sulit untuk dibuktikan secara materiil maka pembuktian adanya unsur kesengajaan dalam pelaku melakukan tindakan melanggar hukum sehingga perbuatannya itu dapat dipertanggung jawabkan kepada si pelaku seringkali hanya dikaitkan dengan keadaan serta tindakan si pelaku pada waktu ia melakukan perbuatan melanggar hukum yang dituduhkan kepadanya tersebut.

Disamping unsur kesengajaan di atas ada pula yang disebut sebagai unsur kelalaian atau kelapaan atau culpa yang dalam doktrin hukum pidana disebut sebagai kealpaan yang tidak disadari atau onbewuste schuld dan kealpaan disadari atau bewuste schuld. Dimana dalam unsur ini faktor terpentingnya adalah pelaku dapat menduga terjadinya akibat dari perbuatannya itu atau pelaku kurang berhati-hati.

Wilayah culpa ini terletak diantara sengaja dan kebetulan. Kelalaian ini dapat didefinisikan sebagai apabila seseorang melakukan sesuatu perbuatan dan perbuatan itu menimbulkan suatu akibat yang dilarang dan diancam dengan hukuman oleh 
undang-undang, maka walaupun perbuatan itu tidak dilakukan dengan sengaja namun pelaku dapat berbuat secara lain sehingga tidak menimbulkan akibat yang dilarang oleh undang-undang, atau pelaku dapat tidak melakukan perbuatan itu sama sekali.

Dalam culpa atau kelalaian ini, unsur terpentingnya adalah pelaku mempunyai kesadaran atau pengetahuan yang mana pelaku seharusnya dapat membayangkan akan adanya akibat yang ditimbulkan dari perbuatannya, atau dengan kata lain bahwa pelaku dapat menduga bahwa akibat dari perbuatannya itu akan menimbulkan suatu akibat yang dapat dihukum dan dilarang oleh undang-undang.

Penerapan unsur kelalaian di dalam kecelakaan lalu lintas dalam berkas perkara yang diteliti dapat dibuktikan melalui pemeriksaan Tersangka di mana menerangkan bahwa benar kejadian kecelakaan lalu lintas yang saya alami terjadi pada pada hari Rabu tanggal 10 April 2013 sekira jam 09.00 Wib, dan tempat kejadiannya di jalan A. Yani Slawi Wilayah Kelurahan Procot Kec. Slawi Kab. Tegal tepatnya di Jalan depan Pengadilan Negeri Slawi. Tersangka menerangkan bahwa benar kejadian kecelakaan lalu lintas tersebut antara Kbm Toyota Kijang No.Pol G-8681-D tahun pembuatan 1994 yang saya kemudikan kemudian oleng dan menabrak Spm honda Supra X 125 No.Pol. G-3160-BZ dan menabrak tembok taman serta pohon. Tersangka menerangkan bahwa benar pada saat kejadian kecelakaan lalu lintas tersebut saya mengemudikan Kbm Toyota Kijang No.Pol. G8681-D tidak tahu berapa orang yang naik di Mobil yang saya kemudikan namun setelah kejadian baru tahu bahwa Mobil kijang yang saya kemudikan tersebut dinaiki oleh 9 ( sembilan ) orang yang semuanya karyawan perhutani KPH Pekalongan Barat sedang 
dalam perjalanan dari Terminal Slawi menuju kantor Perhutani KPH Pekalongan Barat di Adiwerna Tersangka menerangkan bahwa benar saya kenal dengan 9 ( sembilan ) orang tersebut yaitu 1). saudara HARYOSO, 2). AMINUDIN, 3). SUBAGDO, 4). WIDODO, 5). AMIRUDIN AZIZ, 6). PURNOMO, 7). PURWANTO, 8). KHOLID dan 9). Saudara SURYAMAN semuanya karyawan Perhutani KPH Pekalongan barat.

Dari uraian keterangan tersangka, dapat dikatakan bahwa ada hubungan antara batin pelaku dengan akibat yang timbul karena perbuatannya itu atau ada hubungan lahir yang merupakan hubungan kausal antara perbuatan pelaku dengan akibat yang dilarang itu, sehingga kepada tersangka dapat diterapkan unsur kealpaan yang mengakibatkan meninggalnya orang lain yang diatur di dalam Pasal 310 Undang-undang Nomor 22 Tahun 2009 tentang Lalu Lintas dan Angkutan Jalan di mana di dalam Pasal 310 ayat (4) Undang-undang Nomor 22 Tahun 2009 tentang Lalu Lintas dan Angkutan Jalan memiliki unsur-unsur sebagai berikut unsur setiap orang, unsur yang mengemudikan kendaraan bermotor, unsur karena lalai dan unsur mengakibatkan meninggalnya orang lain.

\section{Kendala-kendala di dalam Penerapan Unsur Kealpaan} dalam Proses Penyidikan Tindak Pidana Kecelakaan Lalu Lintas Nomor BP/09/V/2013 di Polres Tegal

a. Kurang responsnya masyarakat, karena kebanyakan masyarakat kurang memahami masalah hukum terutama mengenai kelalaian atau kealpaan yang mengakibatkan meninggalnya orang lain di dalam kejadian kecelakana lalu lintas adalah merupakan suatu tindak pidana yang telah diatur 
di dalam ketentuan pidana, dan terhadap pelakunya dapat dijerat dengan $\mathrm{p}[$ idana penjara.

b. Adanya anggapan dari sebagian masyarakat bahwa kecelapaan lalu lintas merupakan suatu musibah sehingga terhadap pelaku atau tersangka tidak dapat dituntut pidana. Snggapan tersangka dan masyarakat pada umumnya bahwa kecelakaan yang terjadi di jalan raya merupakan kecelakaan murni dan tidak dapat dipertanggungjawabkan secara pidana sehingga masyarakat terutama korban akan memaafkan terhadap tersangka tindak pidana kealpaan ini. Seperti yang terjadi di dalam kasus Kecelakaan Lalu Lintas Nomor BP/09/V/2013 di Polres Tegal di mana tersangka adalah teman-teman korban sendiri yang bersama-sama dengan tersangka dan para korban juga berpendapat bahwa tersangka juga merupakan korban dari peristiwa kecelakaan tersebut sehingga tidak dapat dibawa ke ranah hukum pidana. Pernyataan keterangan para saksi di dalam pemeriksaan saksi juga lebih menguntungkan dan membela tersangka karena tidak ada unsur dendam kepada tersangka apalagi menyalahkan tersangka sebagai pelaku suatu tindak pidana.

c. Sulitnya mendapatkan saksi di dalam proses penyidikan kealpaan yang mengakibatkan meninggalnya orang lain dalam kasus kecelakaan, karena di dalam kasus kecelakaan biasanya masyarakat yang sebenarnya mengetahui kejadian tersebut khawatir bila masuk dalam lingkaran suatu kasus pidana, apalagi yang berkenaan dengan penyidikan.

d. Terbatasnya anggaran pemerintah untuk melakukan sosialisasi terhadap Undang-undang Nomor 22 Tahun 2009 tentang Lalu Lintas dan Angkutan Jalan, sehingga sejak diundangkannya 
Undang-undang tersebut hingga saat ini, banyak masyarakat yang belum memahami ketentuan-ketentuan pengaturan baik pengaturan berlalu lintas maupun yang berkenaan dengan ketentuan-ketentuan pidana di dalam Undang-undang Nomor 22 Tahun 2009 tentang Lalu Lintas dan Angkutan Jalan ini, apalagi yang berkenaan dengan keapaan yang mengakibatkan meninggalnya orang lain di dalam kejadian kecelakaan lalu lintas.

\section{PENUTUP}

\section{Kesimpulan}

Penerapan terhadap Tindak Pidana Kecelakaan Lalu Lintas Nomor BP/09/V/2013 di Polres Tegal adalah ketika hubungan antara batin pelaku dengan akibat yang timbul karena perbuatannya itu atau ada hubungan lahir yang merupakan hubungan kausal antara perbuatan pelaku dengan akibat yang dilarang itu, sehingga kepada tersangka dapat diterapkan unsur kealpaan yang mengakibatkan meninggalnya orang lain yang diatur di dalam Pasal 310 Undangundang Nomor 22 Tahun 2009 tentang Lalu Lintas dan Angkutan Jalan, Kendala-kendala dalam Penerapan terhadap Tindak Pidana Kecelakaan Lalu Lintas Nomor BP/09/V/2013 di Polres Tegal adalah kurang responnya masyarakat karena kurang memahami masalah hukum, adanya anggapan dari masyarakat bahwa kecelakana lalu linta smrp musibah sehingga tersangka tidak dapat dituntut, sulitnya mendapatkan saksi karena kekhawatiran bila masuk dalam lingkaran kasus dan terbatasnya anggaran pemerintah untuk sosialisasi Undang-undang Nomor 22 Tahun 2009 tentang Lalu Lintas dan Angkutan Jalan Raya sehingga tidak semua masyarakat memahami. 


\section{Saran}

Diperlukan sosialisasi dan peningkatan kesadaran serta perlindungan terhadap masyarakat dalam memberikan keterangan yang sejelas-jelasnya mengenai suatu tindak pidana kecelakaan karena unsur kealpaan, karena anggapan di masyarakat bahwa kelalaian/kealpaan apalagi yang menyebabkan kematian bukan merupakan tindak pidana karena masyarakat tersebut merasa tidak berbuat apalagi menyebabkan orang lain meninggal. Pihak keluarga korban pun biasanya bisa menerima dan memaklumi kecelakaan yang terjadi pada anggota keluarganya atau mungkin malah korban sendiri yang kurang hati-hati sehingga menyebabkan terjadinya kecelakaan tersebut, bagi penyidik khususnya di dalam penyidikan tindak pidana kecelakaan lalu lintas karena adanya kelalaian yang menyebabkan kematian orang lain agar di dalam penyidikan mengumpulkan dan memperhatikan dengan cermat alat-alat bukti yang ditemukan di Tempat Kejadian Perkara, karena sebagian masyarakat menganggap dalam peristiwa ini matinya seseorang tidak ada hubungannya dengan tindak kejahatan sehingga banyak masyarakat yang tidak sengaja menghilangkan barang-barang bukti yang semestinya sangat menentukan di dalam proses pembuktian nanti. 


\section{DAFTAR PUSTAKA}

\section{A. Buku}

A.A. Oka Mahendra,1996, Menguak Masalah Hukum, Demokrasi dan Pertahanan, Sinar Harapan, Jakarta

Abdul Wahid dan Moh. Muhibbin, 2009. Etika Profesi Hukum, Rekonstruksi Citra Peradilan di Indonesia, Bayu Media, Jakarta

Adam Chazaiwi., 2005, Tindak Pidana mengenai Kesopanan, Penerbit PT RajaGrafindo Persada, Jakarta

Andi Hamzah, 1994, Asas-asas Hukum Pidana,Rhineka Cipta, Jakarta

Andri Winjaya Laksana, Suratman, Analisis Yuridis Penyidikan Tindak Pidana Pornografi Berdasarkan Undang-Undang Nomor 44 Tahun 2008 Di Era Digitalisasi, Jurnal Pembaharuan Hukum, Volume I No. 2 Mei - Agustus 2014

J.E. Jonkers, 1987, Buku Panduan Hukum Pidana Hindia Belanda, Bina Aksara, Jakarta

Karjadi, 1978. Polisi Filsafat dan Perkembangan Hukumnya, Politea, Bogor

Leden Marpaung, 1999. Tindak Pidana terhadap Nyawa dan Tubuh, Sinar Grafika, Jakarta

OC Kaligis, 2006, Perlindungan Hukum Atas Hak Asasi Tersangka, Terdakwa dan Terpidana,Alumni, Bandung

SA. Soehardi, 2004, Polisi Penegak Hukum yang Pelayan. CV. Media Agung Persada, Semarang

Salim HS dan Erlies Septiana Nurbani, 2013, Penerapan Teori Hukum pada Penelitian Tesis dan Disertasi, Raja Grafindo Persada, Jakarta

Satjipto Rahardjo, 1983, Masalah Penegakan Hukum; Suatu Tinjauan Sosiologis, Jakarta: Badan Pembinaan Hukum Nasional Departemen Kehakiman

Satochid Kartanegara, 1993, Hukum Pidana Kumpulan Kuliah, Balai 
Lektur Mahasiswa, Jakarta

Soerjono Soekanto, 1982, Penelitian Hukm Normatif Suatu Tinjauan Singkat, Rajawali., Jakarta

--------------------, 1983, Faktor-faktor yang Mempengaruhi Penegakan Hukum, Jakarta: PT. RajaGrafindo Persada

Sudarto, 1983, Hukum Pidana I, Yayasan Soedarto, Semarang

Teguh Prasetyo,2010, Hukum Pidana, Rajawali Press, Yogyakarta

William Shrode \& Voich, 1974. Organization and Management - Basic Systems Conncept, Tallahassee. Fl. Florida State University

Wirjono Prodjodikoro, 1962, Hukum Acara Pidana di Indonesia, Alumni. Bandung

\section{B. Perundang - Undangan}

Undang - Undang Republik Indonesia Nomor 20 Tahun 2003 tentang Sistem Pendidikan Nasional

Kitab Undang-undang Hukum Pidana

Kitab Undang-undang Hukum Acara Pidana

Undang-undang Nomor 2 Tahun 2002 tentang Kepolisian Negara

Republik Indonesia

Penjelasan SKEP No. Pol. Skep/765/X/2005 tentang Pola Pembinaan Sistem Keamanan Dan Ketertiban Masyarakat Swakarsa

Undang-undang Nomor 22 Tahun 2009 tentang Lalu Lintas dan Angkutan Jalan

Berkas Perkara Nomor BP/09/V/2013/Reskrim dalam Kecelakaan Lalu Lintas 